\title{
A Journey of Self-Actualization of Amir in The Kite Runner
}

\author{
Juan $\mathrm{Du}^{1}$ \\ ${ }^{1}$ School of Foreign languages, Inner Mongolia University for Nationalities, Tongliao, Inner Mongolia, China \\ Correspondence: Du Juan, School of Foreign languages, Inner Mongolia University for Nationalities, Tongliao, \\ China. E-mail: dujuan199507@163.com
}

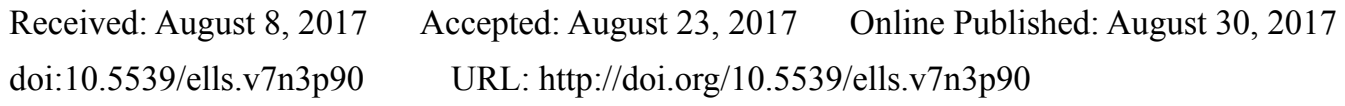

\begin{abstract}
The Kite Runner is Khaled Hosseini's debut novel, which not only shows a person's spiritual growth, but also the history of the soul of a nation, and of a country's suffering. It is about a journey of salvation and return of humanity. This journey can be viewed as going beyond religious, social and economic acceptance; it is a journey of self discovery while accepting the past. Through the analysis of the experiences of Amir from innocence to maturity, from betrayal to salvation, this paper attempts to reveal that on Amir's way to redemption for what he did to Hassan, he has obtained the power of pursuit of love, loyalty, responsibility, dignity and courage. His cowardice and selfishness as well as suffering from conscience and condemnation and torture transform gradually into strong qualities. Therefore, this journey cannot merely be seen as self actualization of the protagonist himself but also the return of humanity of the whole human race.
\end{abstract}

Keywords: self-actualization, humanity, spiritual journey

\section{Introduction}

The Kite Runner is the first novel of Khaled Hosseini who is an Afghan American novelist. In 2006, Hosseini received a humanitarian award of the United Nations, and was invited to serve as the UN Refugee Agency UNHCR goodwill ambassador because of the international influence of his works. With its vivid characters and moving and amazing plots, the novel draws considerable publicity and comments from the critical world after its publication. Tony Sims from Wired Magazine wrote that the book "reveals the beauty and agony of a tormented nation as it tells the story of an improbable friendship between two boys from opposite ends of society" (Sims, 2011). The Washington Post Book World states that it is an intimate account of family and friendship, betrayal and salvation that requires no atlas or translation to engage and enlighten us. Meanwhile, NBC News labels it as the reflection of Afghanistan culture by saying "One of the great strengths of The Kite Runner is its sympathetic portrayal of Afghans and Afghan culture. Hosseini writes with warmth and enviable familiarity about Afghanistan and its people... a descriptive and easily readable account" (Italie, 2012). Chilean writer Isabel Allende considers the novel as "extraordinary" with love, honor, guilt, fear, and redemption. Comparatively speaking, domestic research on the novel and its author has not been abundant. Most of them can be classified into the following aspects: bildungsroman features, social and political issues, symbolism and character analysis. Nevertheless, readers can find spiritual growth of Amir by tracing his experiences. Amir escapes because of cowardice and jealousy during his childhood. Afterwards he has to suffer from long-term psychological torture. Finally, he gets self salvation by saving Hassan's son, and completes his growth.

Thus the purpose of writing this paper is to reveal that on Amir's way to redemption for what he did to Hassan, he has obtained the power of pursuit of love, loyalty, responsibility, dignity and courage because it is the only way to relieve himself of his sin he committed. In the novel, Amir is not a hero, whom Hosseini intentionally portraits as an ordinary person in struggle, a lonely man with low self-esteem. Due to the inner flaws, the image of Amir is much more real and dynamic. His cowardice and selfishness as well as suffering from conscience, condemnation and torture become transformed gradually into strong qualities, which deserve highly appreciation. In this way, the journey of Amir from bewilderment, betrayal to redemption cannot merely be seen as self actualization of the protagonist himself but also the return of bright side of humanity of a common person as well.

\section{The Process of Self-Actualization of Amir}

Self-actualization is a term which was originally introduced by Kurt Goldstein for the motive to realize one's full potential. Expressing one's creativity, quest for spiritual enlightenment, pursuit of knowledge, and the desire to 
give to and/or positively transform society are examples of self-actualization (Goldstein, 1993). Carl Rogers (2015) used the term self-actualization as the actualization of the individual's sense of self. In person-centred theory, self-actualization is the ongoing process of maintaining and enhancing the individual's self-concept through reflection, reinterpretation of experience, allowing the individual to recover, develop, change and grow. As researcher Rui Yuping (2004) claims that Amir's self-actualization follows the pattern: naive temptation-ran away from home - confusion - experiment and test—lost innocence — be insightful—awareness of life and self.

\subsection{The Naive Childhood}

Amir had a happy and naive childhood. The story took place in Kabul, Afghan. Amir and Hassan, the son of a servant were like brothers and close friends. Hassan is "the all-sacrificing Christ-figure, the one who, even in death, calls Amir to redemption" (Rankin-Brown, 2008). He always helped and protected Amir. He was a kind boy and "never denied me anything." (Hosseini, 2007, p. 25)

Amir's father did not show too much care to Amir. So Amir was confused and he was so naive that he thought he could change this by constantly trying to please his father. As a result, he made a serious mistake later.

\subsection{The Betrayal During Adolescence}

In order to get his father's love, Amir attended the kite-fighting tournament and he wanted to be the winner, which was the fuse of his lost. Then Hassan decided to help him. Because of cowardice, Amir hid himself and witnessed the scene of Hassan being insulted.

At that time, Amir was conflicted. He had to make a decision whether to protect Hassan from their hurt or not. "I could step into that alley, stand up for Hassan-the way he'd stood up for me all those times in the past-and accept whatever would happen to me. Or I could run." (Hosseini, p. 78) In the end, Amir ran. Although he was very contradictory in mind, he chose the evil behavior at last. He was fully aware of his choice: "I ran because I was a coward. I was afraid of Assef and what he would do to me. I was afraid of getting hurt. ...I actually aspired to cowardice, because Assef was right: Nothing was free in this world." (Hosseini, p. 78)

To make it worse, in order to escape from shame and guilt, Amir put his money and watch in Hassan's house and said Hassan stole it. Then, Hassan admitted it, and left with his father later. Amir didn't do anything to let them stay at his home. In Amir's sub consciousness, he would leave Hassan behind at any time no matter how faithful Hassan was to him: "If this were one of the Hindi movies Hassan and I used to watch, this was the part where I'd run outside, my bare feet splashing rainwater. I'd chase the car, screaming for it to stop. I'd pull Hassan out of the backseat and tell him I was sorry, so sorry, my tears mixing with rainwater.” (Hosseini, p. 112) He just stepped back and saw Hassan struggling by his own. He betrayed Hassan and lost himself.

\subsection{The Redemption During Adulthood}

Winkler (2007) suggests Hosseini constructs a world where redemption is at least possible. In the universe of the nivel, one can return to the site of his misdeeds. This is action instead of inaction; bravery instead of cowardice; selflessness instead of self-absorption. Perhaps this streak of good deeds will atone for his betrayal of Hassan.

In order to wash his sin, Amir decided to face his past. He returned to Kabul and saved Hassan's son Sohrab. In the process of saving Sohrab, he met Assef who was an evil person. In fact, Amir was very scared of him and had been thinking about escaping there. But finally, he insisted on and stayed there to accept Assef's challenge. Fortunately, he saved Sohrab and himself. It was the first time Amir had felt peaceful in his mind since his childhood.

He laughed because his sin began to be washed. He remembered the day on the hill he had pelted Hassan with pomegranates and tried to provoke him: Hassan'd just stood there, doing nothing, red juice soaking through his shirt like blood. Then he'd taken the pomegranate from Amir's hand, crushed it against his forehead. "Are you satisfied now?" Hassan'd hissed, "Do you feel better?" Obviously, Amir hadn't been happy but bad instead. When Amir was beaten by Assef, he felt better, though he was hurt seriously. "My body was broken — just how badly I wouldn't find out until later-but I felt healed. Healed at last. I laughed."(Hosseini, p. 201) At this point, he had been healed. He completed his self-redemption.

\section{The Return of Humanity}

"There is a way to be good again." (Hosseini, p. 2) As a core image in the novel, kite is a symbol of friendship, justice, kindness, honesty, brave and wisdom. According to Rebecca (2009), the pursuit of kite is actually pursuing the exploration of the better human nature. The two main kite fights in the novel-the tournament Amir wins and the one at the end - symbolize the juxtaposition of roles, for at the end Amir has become the kite runner. Thus, kite symbolizes the interrelationship between betrayal and redemption. The pursuit of the kite is the pursuit of human nature; the fighting of the kite becomes the metaphor of Amir's frustration and rebirth. Interactions with significant 
others are key to the process of self-actualization: "As a result of interaction with the environment, and particularly as a result of evaluational interaction with others, the structure of the self is formed - an organized, fluid but consistent conceptual pattern of perceptions of characteristics and relationships of the "I" or the "me", together with the values attached to these concepts" (Rogers, 2015, p. 15).

\subsection{The Positive and Negative Guiders}

Rahim Khan was the main positive guider. He was the best friend and business partner of Amir's father. When Amir was a child, his father often left him and criticized him. Every time Rahim Khan would help Amir. He was not only Amir's elder, but also more like his friend: he always treated Amir equally, and encouraged him. Rahim Khan thought Amir was good at writing and reading and enjoyed these very much. He was wise and knew how to respect Amir. Many years later, he pointed a way out for Amir to be good again, and this becomes the key to Amir's maturity. Rahim Khan not only focused on Amir's interest, but also cared about Amir's growing. He knew Amir's sin, but he was so patient that he didn't say out and just waited Amir to admit his faults himself. Later, he was ill, and so he told Amir all facts and believed Amir could bear those: "A man who has no conscience, no goodness, does not suffer. I hope your suffering comes to an end with this journey to Afghanistan...." (Hosseini, p. 118) He knew that Amir was so eager for his father's love and how hard Amir had tried to get it. He helped Amir understand and forgive his father eventually.

In the novel, Amir's father was a handsome man who was a force of nature, a towering Pashtun specimen. He was a brave man who would stand up for justice. On the way to Pakistan, his father risked being shot by Russian soldiers in order to protect a young woman. Amir was inspired by his father's courage. Even when Amir went back to rescue Sohrab, this scene was repeated in his mind. "That night, I'm afraid, ultimately, very proud." (Hosseini, p. 116)

Rahim Khan understood everything Amir's father did such as feeding the poor on the streets, building the orphanage, giving money to friends in need and so on. It was his way of redemption. As Rahim Khan said that was what he wanted him to understand, that good, real good, was born out of his father's remorse, when guilt led to good.

However, Amir's father was also the negative guider. Hill (2003) claims that Amir's motivation for the childhood betrayal is rooted in his insecurities regarding his relationship with his father. As a father, he was cold and curt. He didn't care about Amir's feelings. He had no patience with Amir. He taught Amir to be honest and told Amir that there was only one sin, only one, and that was theft; every other sin is a variation of theft. "There is no act more wretched than stealing, Amir." (Hosseini, p. 196) He regarded theft as the most serious sin in the world, but he was the thief himself. And a thief of the worst kind, because the truth was scaring that Amir had a brother, from Hassan his identity, and from Ali his honor. From this point, Amir's father was also a negative guider.

\subsection{The Positive Companions}

Hassan and Soraya accompanied the growth of Amir, and they helped Amir regain his humanity. Hassan was the most faithful companion of Amir. As a Hazara, Hassan was often looked down upon and insulted by others. However, he never showed his resistance. But when Amir encountered any trouble, he would stand up and fence them off. For Amir's glory, Hassan would rather be beaten and humiliated than give up the kite because he knew how important the kite was to Amir. "For you, a thousand time over" was Hassan's promise to his master which showed how committed Hassan was to Amir. Although Hassan's mother abandoned him, many years later, when she came back, Hassan welcomed her and even nursed her to death. Hassan knew that Amir betrayed him, but he never hated him and finally forgave him. When Amir set Hassan up by telling Baba that Hassan had stolen his watch and money, Hassan admitted and apologized as if he did. He accepted the shame and sacrificed himself to save the friendship between them. Moreover, he had never resented anyone because he had his own belief. Two decades later, he even wrote a letter to Amir and expressed his desire for reconciliation. Hassan was an honest, kind, brave, pure, tolerant, considerate and loyal man. He, who was like a mirror, helped Amir find out his weaknesses in his character, and set a good example of kindness, forgiveness, loyalty and justice for Amir. His merit initiated Amir's self actualization.

Soraya was Amir's wife. She was also a key figure in the process of Amir's self-redemption. Because of her appearance and help, Amir began to think about his past. This laid a certain psychological foundation for Amir to have the power to go on the road of self-salvation. Before they got married, Soraya confessed to Amir that when she was 18 years old, she had lived with a drug man together for nearly a month. But later her father forced her to leave the man and took her home. Amir envied Soraya for her courage because she had spoken out her secret. He opened his mouth and almost told her how he'd betrayed Hassan, lied, driven him out, and destroyed a forty-year relationship between his father and Ali. Despite all the improvements and good deeds, Amir remained silent about 
his past deeds. Little by little, he was inspired by her. He started to admit his faults and guilt. After he had saved Sohrab, he told her everything. Having known Amir's past, she didn't show any disgust or doubt. She still loved him. What's the most important is that her understanding of Amir had a good effect on Amir, which drove him to bring Sohrab home. Soraya was not only a loyal wife, but also the positive companion on Amir's road of growth.

\subsection{The Different Growing Places}

Amir grew up, changed, and was affected by where he was living - whether that was Afghanistan or California. Kabul of Afghan was the growing background of Amir's childhood. It was a peaceful and beautiful place before the war broke up. In Kabul, Amir belonged to upper class. Almost everyone showed respect for him. He needn't face the pressure from the outside world. What's more, he had a faithful servant who always helped and protected him. He was a master who could get almost everything that he wanted. After the war broke up, he and his father had to escape to America. There everything had changed. Although he got his degree in the university, got married with his lover and became an excellent writer in the US, and everything seemed to be perfect, he still hadn't the sense of belongingness. Moreover, during the first few years, Amir and his father were lower class in America. Somehow America was a new place which could hide the past; it allows him blankness, a forgetfulness that would be impossible in Afghanistan. Everything he experienced in America sped up his growing up. With different social status, Amir had totally different experiences in two countries. It helped Amir understand different social values among different classes, races, and more important, humanity (Jefferess, 2009).

\section{Conclusion}

The Kite Runner bears a typical theme of growth. Amir finally completed his self salvation and became mature. After suffering from psychological torment, which raises him to a new height and makes him realize and correct the past mistakes, Amir enters a realm in the spirit of transcendence. The glory and darkness of human nature are two sides inside a person. Self-actualization is both the process of self discovery and the return of the bright side of human nature. A personal growth may represent all of ours. Just as the writer Hosseini describes: behind every dusty face has a soul, and determined to flick over ordinary Afghans face's dust, which will be displayed behind the "soul" to the world.

\section{References}

Goldstein, quoted in Arnold H. Modell. (1993). The Private Self (p. 44). Harvard.

Hill, A. (2003). An Afghan hounded by his past. The Guardian. Retrieved from https://www.theguardian.com/books/2003/sep/07/fiction.features1

Hosseini, K. (2007). The Kite Runner. New York: Penguin.

Italie, H. (2012). "Kite Runner" author to debut new novel next year. NBC News. Retrieved from https://en.wikipedia.org/wiki/The_Kite_Runner\#cite_note-Italie-4

Jefferess, D. (2009). To be good (again): The Kite Runner as allegory of global ethics. Journal of Postcolonial Studies, 45. https://doi.org/10.1080/17449850903273572

Rankin-Brown, M. (2008). The Kite Runner: Is Redemption Truly Free?. Spectrum Magazine. Retrieved from https://en.wikipedia.org/wiki/The_Kite_Runner\#cite_note-RB-19

Rogers, C. R. (1951/2015). Client-centred therapy (p. 489). London: Robinson.

Rui, Y. P. (2004). Study on Americam Bildungsroman (p. 84). Beijing: Social Sciences Press.

Sims, T. (2011). GeekDad Interview: Khaled Hosseini, Author of The Kite Runner. Wired. Retrieved from https://www.wired.com/geekdad/2011/09/geekdad-interview-khaled-hosseini-author-of-the-kite-runner/

Stuhr, R. (2009). Reading Khaled Hosseini. Calif: Greenwood Press.

Winkler, L. K. (2007). A Study Guide to Khaled Hosseini’s The Kite Runner. New York: Penguin Group.

\section{Copyrights}

Copyright for this article is retained by the author, with first publication rights granted to the journal.

This is an open-access article distributed under the terms and conditions of the Creative Commons Attribution license (http://creativecommons.org/licenses/by/4.0/). 